\title{
Prevalence of and factors influencing postnatal depression in a rural community in South Africa
}

\author{
Authors: \\ Ethelwynn L. Stellenberg ${ }^{1}$ \\ Johanna M. Abrahams ${ }^{1}$ \\ Affiliations: \\ ${ }^{1}$ Division of Nursing, \\ Stellenbosch University, \\ South Africa \\ Correspondence to: \\ Ethelwynn Stellenberg \\ Email: \\ elstel@sun.ac.za

\section{Postal address:} \\ PO Box 241, Francie van Zijl \\ Drive, Cape Town 8000, \\ South Africa

\section{Dates:} \\ Received: 30 Apr. 2015 \\ Accepted: 11 Sept. 2015 \\ Published: 24 Nov. 2015 \\ How to cite this article: \\ Stellenberg EL, Abrahams \\ JM. Prevalence of and \\ factors influencing postnatal \\ depression in a rural \\ community in South Africa. \\ Afr J Prm Health Care Fam \\ Med. 2015;7(1), Art. \#874, \\ 8 pages. http://dx.doi \\ org/10.4102/phcfm.v7i1.874

\section{Copyright:} \\ (C) 2015. The Authors. \\ Licensee: AOSIS \\ OpenJournals. This work is \\ licensed under the Creative \\ Commons Attribution \\ License.
}

\section{Read online:}

Scan this QR
code with your
smart phone or
mobile device
to read online.

Background: Knowledge about postnatal depression (PND) and associated risk factors which influence the development of PND is vital for early detection, intervention and prevention.

Setting: The study was conducted in primary health care clinics (PHC) in the Witzenberg subdistrict, a rural community in South Africa.

Objectives: Objectives of this study were to determine the prevalence of PND and to identify the contributing risk factors associated with PND.

Methods: A descriptive cross sectional research design with a quantitative approach was applied. The target population was mothers, 18 years and older. A convenience sampling method was used to select a sample of 159 (10\%) from a population of 1605 live births. The Edinburgh Postnatal Depression Scale (EPDS) and Beck Depression Inventory (BDI), two validated self-rating questionnaires, including a questionnaire based on demographical, psychosocial and obstetrical data, were applied. The data was analysed using various statistical tests to determine statistical associations between variables using a 95\% confidence interval.

Results: PND was a serious health problem with 50.3\% of the mothers who suffered from PND. A BDI analysis showed that of the participants who had PND, 28.8\% was severe, $48.8 \%$ moderate and $22.5 \%$ mild. Factors influencing the development of PND included most participants (63.5\%) were unmarried, $61.3 \%$ were unemployed and the majority $(53.8 \%)$ had a history of a psychiatric illness. Significant associations between PND and unplanned and unwelcome babies $(p<0.01)$; partner relationship $(p<0.01)$; were identified.

Conclusion: Prevention, early detection, appropriate referral and treatment of PND are critical in managing maternal, child and family well-being.

Prévalence de, et facteurs qui influencent la dépression postnatale dans une communauté rurale d'Afrique du Sud.

Contexte: Une connaissance de la dépression postnatale (DPN) et des facteurs de risque connexes qui influencent le développement de la DPN est essentielle pour la détection précoce, l'intervention et la prévention.

Lieu: L'étude a été menée dans des cliniques de santé primaire (CSP) du sous-district de Witzenberg, une communauté rurale d'Afrique du Sud.

Objectifs: Cette étude avait pour objet de déterminer la prévalence de la DPN et d'identifier les facteurs de risques liés à la DPN.

Méthodes: On a utilisé un plan de recherche transversal descriptif avec une approche quantitative. La population visée était des mères de 18 ans et plus. On a fait appel à une méthode d'échantillonnage représentative pour sélectionner un échantillon de 159 (10\%) personnes sur une population de 1605 naissances vivantes. On a appliqué l'Echelle de Dépression Postnatale d'Edinburgh (EDPE) et l'Inventaire de Dépression de Beck (IDB), deux questionnaires autoévalués et validés, comprenant un questionnaire basé sur des données démographiques, psychosociales et obstétriques. On a analysé les données au moyen de différents tests statistiques pour déterminer les associations statistiques entre les variables avec un intervalle de confiance de $95 \%$.

Résultats: La DPN est un grave problème de santé avec $50.3 \%$ des mères qui en souffrent. Une analyse IDB a montré que parmi les participantes souffrant de DPN, 28.8\% étaient sévèrement affectées, $48.8 \%$ modérément et $22.5 \%$ légèrement. Les facteurs influençant le développement de la DPN étaient que la plupart des participantes $(63.5 \%)$ n'étaient pas mariées, $61.3 \%$ étaient au chômage et la majorité (53.8\%) avait des antécédents de maladie psychiatrique. On a aussi remarqué des liens entre la DPN et les bébés non planifiés et non désirés $(p<0.01)$; et la relation des partenaires $(p<0.01)$.

Conclusion: La prévention, la détection précoce, l'orientation vers le service et le traitement appropriés de la DPN sont critiques pour la gestion du bien-être de la mère, de l'enfant et de la famille. 


\section{Introduction}

\section{Social value}

Depression is associated with substantially reduced quality of life and functional capacity for the affected woman with PND. ${ }^{1}$ Poor maternal mental health is especially problematic for the infants of these mothers. The investigation of the prevalence and the factors contributing to PND was fundamental in contributing to the achievement of the Millennium Development Goals, specifically in improving maternal health and reducing child mortality. ${ }^{2}$ The lack of scientific evidence about the prevalence and factors contributing to PND in the Witzenberg subdistrict, Western Cape, South Africa made it essential that this problem was investigated scientifically. Ultimately, this study may contribute to early detection and management of PND and the improvement of the mental health services in the rural community.

Depression is the leading cause of disease burden for women in both high-income and low- and middle income countries. ${ }^{3}$ Despite being a leading cause of disease burden for women, mental health is still the stepchild of health services and even more so in the rural areas. ${ }^{4}$

Postnatal depression (PND) is a severe condition, which can be described as 'a thief who steals maternity'. ${ }^{5}$ The prevalence of PND is currently considered to be $10 \%-$ $15 \%$, but is still increasing and becoming a serious public health problem. ${ }^{6,7}$ In a study conducted in a South African peri-urban settlement, Khayelitsha, a prevalence rate of $34.7 \%$ of mothers at two months' postnatal suffer from PND. ${ }^{8}$ PND affects approximately 500000 mothers in the United States each year, and about one in five mothers may be affected by a major mental disorder in the first 12 months following childbirth. ${ }^{9}$ The seriousness of this condition is further shown in an incident as reported in the IOL News, London, that a 35-year-old woman with PND killed her two babies, a 10-week-old son and 14-month-old daughter. ${ }^{10}$

\section{Scientific value}

PND is a universal and serious mood disorder that occurs within a few weeks after birth and causes considerable risks to the mother, the developing child and the entire family. ${ }^{9}$ The derivations of PND can sometimes be visible during the postnatal period, sometimes referred to as puerperium, but are frequently only fully recognisable months later in the first year after birth. This depression may last for weeks, months or even years after origination. ${ }^{11}$ Therefore, if PND is left untreated, it may lead to affective, cognitive, behavioural and physical problems. This may not only have an extremely negative effect on the mothering role and mother-child relationship, but on the total existence of the affected mother's family. ${ }^{12}$

Almost $10 \%$ of all postnatal mothers will acquire a depressive disorder. ${ }^{13}$ It was further shown that it is most likely to occur in $16 \%$ of women during the postpartum period. ${ }^{14}$ Mental illnesses, especially major depression, add extensively to the non-fatal burden of disease and is the second leading cause of mental disabilities. However, in South Africa the ratio between psychiatrist and patient and/or client is 1:357 142 and psychologist and patient and/or client is 1:312 500,15 making mental illness one of the most neglected illnesses in South Africa. The Annual Health Status Report identified that in the Witzenberg subdistrict there was a marked increase in mental health cases from 347 in 2001 to 491 in 2006. ${ }^{16}$

Depression, anxiety, stressful life events and low levels of social support were identified as key maternal risk factors in studies conducted in Khayelitsha. ${ }^{14,17}$ Nearly one third of employed participants $(32.7 \%)$ in a study stated substantial depressive symptoms at four months postnatal. ${ }^{18}$ Thus, it is evident that PND will influence the mother's capability to care for her baby. ${ }^{19}$

Maternal age is related to PND symptoms but lower socioeconomic and educational levels are added risk factors. ${ }^{20}$ Symptoms of depression are substantially higher amongst mothers with lower educational levels who are unmarried and poor. ${ }^{18}$ PND has been found to be higher in socioeconomically disadvantaged areas in SA, as shown in a study in Khayelitsha, in which the PND rate is as high as $34.7 \%{ }^{8}$

The levels, however, in teenage mothers have been reported to be as high as $26 \%{ }^{6}$ The incorporation of many factors such as integration of biochemistry, hormonal functioning, genetic history and psychosocial factors such as stressful life events concede the potential for the occurrence of PND. ${ }^{6}$

\section{Conceptual theoretical framework}

The conceptual theoretical framework, which guided this study, is based on the clinical or medical model, biopsychosocial model, holistic approach of nursing, and the following psychosocial theories of depression: psychoanalytic theory, object loss theory, learned helplessness theory and the cognitive theory. These models and theories were significant for this study because it is imperative for health care workers to understand depression, the origin thereof, and what the possible causes and consequences are in order to understand and manage clients most effectively.

\section{Aim and objectives}

The objectives of this study were to determine the prevalence of PND and to identify the contributing risk factors associated with PND in the Witzenberg subdistrict of the Western Cape, South Africa.

\section{Research methods and design Study design}

A cross sectional descriptive research design with a quantitative approach was applied in this study. 


\section{Setting}

The study was conducted in four of the eight clinics in the Witzenberg subdistrict, with a population of approximately 115946 in 2011. ${ }^{21}$ The subdistrict under study included the five towns of Ceres, Prince Alfred Hamlet, Op-Die-Berg, Wolseley and Tulbagh, with a rural predominance and a high degree of poverty. ${ }^{22}$

\section{Study population sampling strategy}

The target population included mothers $(N=1605)$ who gave birth during one calendar year and were resident in the Witzenberg subdistrict of the Western Cape. Simple random sampling was used to select four clinics (50\%), two clinics in the lower socio-economic areas and two clinics in the middle socio-economic areas. Mothers ( $\geq 18$ years old) were selected when they brought their babies to the clinics for immunisations at 6-, 10- or 14 weeks. The researcher addressed all the mothers in a group and explained the purpose of the study and requested if there were any mothers who would willingly participate. Thus, 159 mothers, approximately $10 \%$ of the target population, were selected.

\section{Data collection}

Data were collected over a period of four months, once a week at the individual postnatal clinics identified for the purpose of the study. Data collection was done by the researcher with the help of two trained field workers with a nursing background and who were fluent in Afrikaans, English and Xhosa. The field workers were trained beforehand in the interpretation of the different questionnaires and the process of data collection. Their role was to assist with interpretation. The questionnaire was self-administered and where participants had a problem understanding any question, it was explained by the researcher or the trained field worker.

The questionnaire, based on the literature and clinical experience of the PI, was designed and administered to determine the demographical data and psychosocial risk factors of the participants. The questions specifically included aspects about: maternal age, marital status, level of education, pregnancies and children, mode of delivery, psychosocial factors, psychiatric history and social support.

The Edinburgh Postnatal Depression Scale (EPDS) was used to identify postnatal depression. The questionnaire is easy to administer and takes approximately five minutes to complete and is generally accepted by mothers after birth. The questionnaire consists of ten questions specifically about the participant's feelings over the previous seven days, including the day she was interviewed. ${ }^{23}$

The Beck Depression Inventory (BDI) was also used in this study to determine the severity of PND. The BDI (BDI-II), ${ }^{24}$ created by Dr Aaron T. Beck, is a 21-question multiple-choice self-report inventory and is one of the most widely used instruments for measuring the severity of depression. Each question consists of a set of at least four possible choices, with values ranging in intensity from $0-3 .^{25}$ No values were visible on the participant's copy to minimize the risk of the participant manipulating the outcome, which may lead to answers being chosen because of its specific value. The classification to determine the severity of PND was as follows:

- Score < 15: Mild Depression

- Score 15-30: Moderate Depression

- Score > 30: Severe Depression

\section{Reliability and validity}

The EPDS and BDI are two validated, self-rating questionnaires. The authors ${ }^{23}$ of the EPDS have shown that the 10-item Postnatal Depression Scale had satisfactory validity, splithalf reliability and that it is also sensitive to changes in the severity of depression over time. The BDI is a wellknown screening instrument in the mental health field. It is recommended for research, as well as in the clinical setting for its reliability and validity. The reliability and validity was further ensured through the use of experts in the fields of statistics, nursing and research methodology. The pilot study also added to the validity and reliability because all three instruments were pre-tested and rectified, where required, after the pilot study.

\section{Data analyses}

All data were analysed and interpreted with the support of a qualified statistician. A computer software program, STATISTICA, ${ }^{26}$ was used to analyse the data. Data were expressed in frequencies, tables and histograms. The relationship between continuous response variables and nominal input variables was analysed using analysis of variance (ANOVA). Statistical associations and significance between variables were determined by using a $95 \%$ confidence interval, with a significance level of $(p \leq 0.05)$.

\section{Ethical considerations}

The researchers obtained written permission from the Committee for Human Science Research at the Faculty of Medicine and Health Sciences at Stellenbosch University (ref. N09/11/336). The researchers also received written consent from the Research Coordinating Committee of the Department of Health (RP16/2010), Provincial Government of Western Cape.

\section{Potential benefits and hazards}

The researcher explained the study to all the participants individually and emphasised that their participation was voluntary, and informed written consent was obtained from all participants. The risk foreseen was the sudden breakdown of participants during the interview that may then have required counselling. 


\section{Recruitment procedures}

Participants were informed that participation was voluntary and that they had a choice to withdraw from the study at any stage and that their decision would not influence any further service rendered to them.

\section{Informed consent}

Voluntary written informed consent was obtained from individual participants after providing information about the research. The ethical implications, as well as the aim and objectives for the study, were explained to each participant personally.

\section{Data protection}

Data obtained from the study was coded to protect the identities of the participants and to ensure confidentiality, anonymity and privacy concerning all information. The data is stored in a secure locked cabinet providing access to the researchers only.

\section{Results}

A total of 159 participants participated in the study of which $80(50.3 \%)$ had PND as analysed using the EPDS test (Tables 1 and 2). The BDI test showed that of the participants (80) who had PND, $23(28.8 \%)$ had severe depression, $39(48.8 \%)$ moderate and 18 (22.5\%) mild depression (Table 3).

\section{Demographical and obstetrical factors \\ Marital status}

Aspects about the marital status and depression are shown in Table 1. The majority of the participants 102 (64.2\%) were unmarried and $26(16.4 \%)$ were living with a partner (Table 1). The maternal age of participants indicated that 38 (23.9\%) were teenagers, age 18-19 years, of which 19 (50\%) had PND. The BDI test revealed that amongst the teenagers, $21.7 \%$ had severe depression, $20.5 \%$ had moderate and $33.3 \%$ had mild depression (Table 3).

A bivariate analysis showed that $45(56.3 \%)$ of the participants who were unmarried, $18(22.5 \%)$ who were married and $16(20 \%)$ who were living with a partner suffered from depression (Table 1).

BDI inventory analysis results showed that of the unmarried participants $56.5 \%$ had severe depression (Table 3 ).

\section{Pregnancies}

Most of the participants $71(44.7 \%)$ had only had one (1) pregnancy followed by $39(24.7 \%)$ who had had two (2) pregnancies. No significant results were obtained between depression and pregnancies.
TABLE 1: Summary of demographical and obstetrical factors as classified according to the Edinburgh Postnatal Depression Scale test.

\begin{tabular}{|c|c|c|c|c|}
\hline $\begin{array}{l}\text { Demographical and } \\
\text { obstetrical factors }\end{array}$ & $\begin{array}{c}\text { All } \\
n=159(\%)\end{array}$ & $\begin{array}{c}\text { Not depressed } \\
n=79(\%)\end{array}$ & $\begin{array}{l}\text { Depressed } \\
n=80(\%)\end{array}$ & $p$-value \\
\hline \multicolumn{5}{|l|}{ Marital status } \\
\hline Married & $29(18.2)$ & 11 (13.9) & $18(22.5)$ & $p=0.17$ \\
\hline Unmarried & $102(64.2)$ & $57(72.2)$ & $45(56.3)$ & \\
\hline Living together & $26(16.4)$ & $10(12.7)$ & $16(20.0)$ & \\
\hline \multicolumn{5}{|l|}{ Teenagers } \\
\hline $\begin{array}{l}\text { Mode of } \\
\text { delivery }\end{array}$ & $38(23.9)$ & $19(24.1)$ & $19(23.8)$ & $\begin{array}{l}p=0.20 \\
p=0.28\end{array}$ \\
\hline Normal births & $133(83.7)$ & $62(78.5 \%)$ & $71(88.7)$ & \\
\hline Caesarean & $25(16.3)$ & $16(20.5 \%)$ & $9(11.3)$ & \\
\hline \multicolumn{5}{|l|}{ Postnatal period } \\
\hline $\begin{array}{l}\text { Postnatal } \\
\text { period } 4\end{array}$ & $53(33.3)$ & $32(40.5)$ & 21 (39.6) & $p=0.05$ \\
\hline $\begin{array}{l}\text { Postnatal } \\
\text { period: } 10 \\
\text { weeks }\end{array}$ & $52(32.7)$ & $22(27.8)$ & $30(57.7)$ & \\
\hline $\begin{array}{l}\text { Postnatal } \\
\text { period: } 14 \\
\text { weeks }\end{array}$ & $54(34.0)$ & $25(31.6)$ & $29(53.7)$ & \\
\hline \multicolumn{5}{|l|}{ Employment } \\
\hline Employed & $64(40.3)$ & $33(41.8)$ & $31(38.8)$ & $p=0.04$ \\
\hline Unemployed & 95 (59.7) & $46(58.2)$ & $49(61.3)$ & \\
\hline \multicolumn{5}{|l|}{ Income } \\
\hline No income & $40(25.1)$ & $21(26.6)$ & $19(23.8)$ & $p=0.57$ \\
\hline Single income & 65 (40.9) & $37(46.8)$ & $28(35.0)$ & \\
\hline Family income & $54(34.0)$ & $21(26.6)$ & $33(41.3)$ & \\
\hline
\end{tabular}

TABLE 2: Factors influencing the development of postnatal depression as classified according to the Edinburgh Postnatal Depression Scale test.

\begin{tabular}{|c|c|c|c|c|}
\hline $\begin{array}{l}\text { Factors influencing } \\
\text { development of } \\
\text { PND }\end{array}$ & $\begin{array}{c}\text { All } n=159 \\
(\%)\end{array}$ & $\begin{array}{c}\text { Not depressed } \\
n=79(\%)\end{array}$ & $\begin{array}{c}\text { Depressed } n= \\
80(\%)\end{array}$ & $p$-value \\
\hline \multicolumn{5}{|l|}{ Psychiatric history } \\
\hline $\begin{array}{l}\text { Psychiatric self- } \\
\text { history }\end{array}$ & 65 (40.9) & $22(27.8)$ & $43(53.8)$ & \multirow[t]{2}{*}{$\begin{array}{l}p<0.01 \\
p=0.24\end{array}$} \\
\hline $\begin{array}{l}\text { Psychiatric } \\
\text { family history }\end{array}$ & $138(86.8)$ & 71 (89.9) & 67 (83.9) & \\
\hline \multicolumn{5}{|l|}{ Life events } \\
\hline $\begin{array}{l}\text { Major life } \\
\text { events }\end{array}$ & $67(42.1)$ & $28(35.4)$ & $39(48.8)$ & \multirow[t]{5}{*}{$p=0.10$} \\
\hline $\begin{array}{l}\text { Minor life } \\
\text { events }\end{array}$ & $39(24.5)$ & $23(29.1)$ & $16(20)$ & \\
\hline No life events & $47(29.6)$ & $26(32.9)$ & $21(26.3)$ & \\
\hline $\begin{array}{l}\text { Major and } \\
\text { minor }\end{array}$ & $5(3.1)$ & $2(2.5)$ & $3(3.8)$ & \\
\hline $\begin{array}{l}\text { Minor and } \\
\text { minor }\end{array}$ & $1(0.6)$ & $0(0.0)$ & $1(1.3)$ & \\
\hline \multicolumn{5}{|l|}{ Partnership } \\
\hline $\begin{array}{l}\text { Unsatisfactory } \\
\text { partnership }\end{array}$ & 65 (40.9) & $21(26.6)$ & $44(55.0)$ & \multirow[t]{2}{*}{$p<0.01$} \\
\hline $\begin{array}{l}\text { Satisfactory } \\
\text { partnership }\end{array}$ & $94(59.1)$ & $58(73.4)$ & $36(45.0)$ & \\
\hline \multicolumn{5}{|c|}{ Family and social support } \\
\hline $\begin{array}{l}\text { Have family } \\
\text { and social } \\
\text { support }\end{array}$ & $123(77.4)$ & $71(89.9)$ & $52(65.0)$ & \multirow[t]{2}{*}{$p<0.01$} \\
\hline $\begin{array}{l}\text { Have no family } \\
\text { and social } \\
\text { support }\end{array}$ & $36(22.6)$ & $8(10.1)$ & $28(35.0)$ & \\
\hline \multicolumn{5}{|l|}{ Baby factors } \\
\hline $\begin{array}{l}\text { Unplanned } \\
\text { babies }\end{array}$ & $96(60.4)$ & $54(68.4)$ & $42(52.5)$ & \multirow[t]{4}{*}{$p=0.03$} \\
\hline Planned babies & $46(28.9)$ & $21(26.6)$ & $25(31.3)$ & \\
\hline $\begin{array}{l}\text { Unwelcome } \\
\text { babies }\end{array}$ & $13(8.1)$ & $3(3.8)$ & $10(12.5)$ & \\
\hline $\begin{array}{l}\text { Unwelcome } \\
\text { sex of baby }\end{array}$ & $4(2.5)$ & $1(1.3)$ & $3(3.8)$ & \\
\hline
\end{tabular}

PND, postnatal depression. 
TABLE 3: Factors influencing the development of postnatal depression showing the severity of depression levels as classified according to the Beck Depression Inventory

test.

\begin{tabular}{|c|c|c|c|c|c|}
\hline $\begin{array}{l}\text { Factors influencing development of } \\
\text { PND }\end{array}$ & $\begin{array}{c}\text { Depression } \\
n=80(50.3 \%)\end{array}$ & $\begin{array}{c}\text { Mild } \\
n=18(22.5 \%)\end{array}$ & $\begin{array}{c}\text { Moderate } \\
n=39(48.8 \%)\end{array}$ & $\begin{array}{c}\text { Severe } \\
n=23(28.8 \%)\end{array}$ & $p$-value \\
\hline \multicolumn{6}{|l|}{ Teenager } \\
\hline Yes & $19(23.8)$ & $6(33.3)$ & $8(20.5)$ & $5(21.7)$ & $p=0.56$ \\
\hline No & $61(76.2)$ & $12(66.7)$ & $31(79.5)$ & $18(78.3)$ & \\
\hline \multicolumn{6}{|l|}{ Marital status } \\
\hline Unmarried & $45(56.3)$ & $13(72.2)$ & $19(48.7)$ & $13(56.5)$ & $p=0.03$ \\
\hline Married & $18(22.5)$ & $1(5.6)$ & $15(38.5)$ & $2(8.7)$ & \\
\hline Living together & $16(20)$ & $4(22.2)$ & $5(12.8)$ & $7(30.4)$ & \\
\hline Widow & $1(1.3)$ & $0(0)$ & $0(0)$ & $1(4.4)$ & \\
\hline \multicolumn{6}{|l|}{ Mode } \\
\hline Normal & $71(88.7)$ & $17(94.4)$ & $33(84.6)$ & $21(91.3)$ & $p=0.47$ \\
\hline Caesarean & $9(11.3)$ & $1(5.6)$ & $6(15.4)$ & $2(8.7)$ & \\
\hline \multicolumn{6}{|l|}{ Employment } \\
\hline Employed & $31(38.8)$ & $9(50)$ & $15(38.5)$ & $7(30.4)$ & $p=0.44$ \\
\hline Unemployed & $49(61.2)$ & $9(50)$ & $24(61.5)$ & $16(69.6)$ & \\
\hline \multicolumn{6}{|l|}{ Income } \\
\hline None & $19(23.8)$ & $5(27.8)$ & $8(20.5)$ & $6(26.1)$ & $p=0.98$ \\
\hline Single & $28(35)$ & 7 (38.9) & $13(33.3)$ & $8(34.8)$ & \\
\hline Family & $33(41.3)$ & $6(33.3)$ & $18(46.2)$ & $9(39.1)$ & \\
\hline \multicolumn{6}{|l|}{ Psychiatric history: Family } \\
\hline Family: Yes & $13(16.3)$ & $3(16.7)$ & $5(12.8)$ & $5(21.7)$ & $p=0.06$ \\
\hline Family: No & $67(83.7)$ & $15(83.3)$ & $34(87.2)$ & $18(78.3)$ & \\
\hline \multicolumn{6}{|l|}{ Psychiatric history: Self } \\
\hline Self: Yes & $43(53.8)$ & 7 (38.9) & $19(48.7)$ & 17 (73.9) & $p \leq 0.01$ \\
\hline Self: No & $37(46.2)$ & $11(61.1)$ & $20(51.3)$ & $6(26.1)$ & \\
\hline \multicolumn{6}{|l|}{ Life events } \\
\hline Major & $39(48.7)$ & $4(22.2)$ & $23(59)$ & $12(52.2)$ & $p=0.01$ \\
\hline Minor & $16(20)$ & $5(27.8)$ & $4(10.3)$ & $7(30.4)$ & \\
\hline $\mathrm{MN}$ and $\mathrm{MJ}$ & $3(3.8)$ & $1(5.6)$ & $0(0)$ & $2(8.7)$ & \\
\hline $\mathrm{MN}$ and $\mathrm{MN}$ & $1(1.3)$ & $1(5.6)$ & $0(0.0)$ & $0(0.0)$ & \\
\hline No life event & $21(26.2)$ & $7(38.9)$ & $12(30.8)$ & $2(8.7)$ & \\
\hline \multicolumn{6}{|l|}{ Partner relationships } \\
\hline Unsatisfactory & $44(55)$ & $3(16.7)$ & $20(51.3)$ & $21(91.3)$ & $p<0.01$ \\
\hline Satisfactory & $36(45)$ & $15(83.3)$ & $19(48.7)$ & $2(8.7)$ & \\
\hline \multicolumn{6}{|l|}{ Baby factors } \\
\hline Unplanned & $42(52.3)$ & $11(61.1)$ & $20(51.3)$ & $11(47.8)$ & $p<0.01$ \\
\hline Planned & $25(31.3)$ & $5(27.8)$ & $14(35.9)$ & $6(26.1)$ & \\
\hline Unwelcome & $10(12.5)$ & $1(5.6)$ & $4(10.3)$ & $5(21.7)$ & \\
\hline $\begin{array}{l}\text { Sex of baby } \\
\text { unwelcome }\end{array}$ & $3(3.8)$ & $1(5.6)$ & $1(2.6)$ & $1(4.4)$ & \\
\hline \multicolumn{6}{|l|}{ Family and/or social support } \\
\hline Yes & $52(65.0)$ & $15(83.3)$ & $28(71.8)$ & $9(39.1)$ & $p<0.01$ \\
\hline No & $28(35.0)$ & $3(16.7)$ & $11(28.2)$ & $14(60.9)$ & \\
\hline
\end{tabular}

\section{Mode of delivery}

The results showed that of the participants $(n=80)$ with PND $88.7 \%$ had normal births (Table 1 ). According to the BDI test 91.3\% had severe depression and $84.6 \%$ moderate depression (Table 3).

\section{Postnatal period 6-10-14 weeks}

Table 1 shows the number of participants at the various time intervals of 6-10-14 weeks. The analysis further showed that $39.6 \%, 57.7 \%$ and $53.7 \%$ of the participants had PND at the particular week intervals 6-10-14 weeks respectively. A significant statistical association $(p=0.02)$ was obtained between the 6-week and 10th week periods with the Bonferroni post-hoc test. A further significant association was identified between the EPDS test and postnatal period $(p=0.05)$ (Table 1).

\section{Employment}

Results showed that $95(59.7 \%)$ of the participants were unemployed of which 49 (61.3\%) of the participants with PND were unemployed. A statistical association was identified between employment and the EPDS test $(p=0.04)$ applying the Mann-Whitney $U$-test (Table 1). According to the BDI test $30.4 \%$ had severe and $38.5 \%$ had moderate depression (Table 3). 


\section{Income}

The results showed that $119(74.9 \%)$ of the participants have an income whilst $40(25.1 \%)$ have no income. A further analysis showed that of the number of participants who suffered from PND 23.8\% of these participants received no income (Table 1). The BDI test revealed that the participants with only a family income $46.2 \%$ had moderate depression whilst $39.1 \%$ had severe depression. No statistical significant difference was shown between the depression and income $(p=0.98)$ (Table 3).

\section{Factors influencing the development of postnatal depression}

\section{Psychiatric history}

Table 2 shows that 65 (40.9\%) had a history of a psychiatric illness, of which $53.8 \%$ of the participants who had PND $(n=80)$ had a history of a psychiatric illness. Using the Mann-Whitney $U$-test a statistical significant association was identified between psychiatric history of the self and depression $(p<0.01)$.

The results further showed that $83.7 \%$ of the participants with PND $(n=80)$ had no family history of psychiatric illnesses. The BDI test showed that participants with no family history $78.3 \%$ had severe depression, $87.2 \%$ moderate and $83.3 \%$ mild depression (Table 3).

\section{Life events}

The results show that $67(42.1 \%)$ of the participants had experienced a major life event which excluded the delivery of a baby, which is a natural event. In addition, results illustrated that of the 80 participants who suffered from PND, $48.7 \%$ experienced major life events, $20 \%$ a minor event and 21 (26.3\%) had no life event experiences (Table 2). According to the BDI test, participants who had a major life event 59\% had moderate depression and 52.2\% severe depression (Table 3).

Furthermore, the study also shows a statistical significant difference between depression and life events using the Chi square test $(\mathrm{df}=8)=19.95,(p=0.01)($ Table 3$)$.

\section{Partner relationship}

Table 2 shows that $65(40.9 \%)$ of participants were in an unsatisfactory partner relationship, of which $55 \%$ of the 80 participants who suffered from PND, were in unsatisfactory relationships with their partners. The BDI test shows that $91.3 \%$ of the participants had severe depression and $51.3 \%$ moderate depression. A statistical significant difference between partner relationship and the EPDS test applying the Mann-Whitney $U$-test was identified $(p<0.01)$ (Table 2$)$ and between partner relationship and depression applying the Chi square test $(\mathrm{df}=2)=26.25(p<0.01)$ (Table 3$)$.

\section{Family and social support}

The majority of the participants $123(77.4 \%)$ received family and social support (Table 2). However, of the participants who suffered from PND 35\% received no family or social support.

The Levene's test for homogeneity of variances effect also showed a significant difference between family or social support and the EPDS test $(p<0.01)$ (Table 2).

A statistical significant difference was shown between family and social support and depression using the Mann-Whitney $U$-test $(p<0.01)$. According to the BDI test, participants who received no family or social support (60.9\%) had severe depression and $11(28.2 \%)$ had moderate depression (Table 3 ).

\section{Baby factors}

The baby factors are defined as those factors associated with the baby which may have contributed to PND, namely unplanned, planned, unwelcome baby or an unwelcome sex of the baby. The majority of participants $96(60.4 \%)$, as shown in Table 2, had unplanned babies. The results further showed that of the 80 participants who suffered from PND, 52.5\% were unplanned pregnancies and $31.3 \%$ were planned babies, $12.5 \%$ were unwelcome and $3.8 \%$ were unwelcome sex of the babies. The Kruskal Wallis test further showed a significant difference between baby factors and EPDS test $(p=0.03)$ (Table 2 ) and between baby factors and depression $(p<0.01)$ (Table $3)$. However to guard against Type 1 error, a post-hoc analysis was done by applying the Bonferoni test using the BDI variable specifically to determine specific statistical differences between the baby factors. The Bonferoni test revealed a statistical significant difference between unplanned and unwelcome babies $(p<0.01)$ and between planned and unwelcome babies $(p<0.01)$. The Bonferoni test was also applied using the EPDS variable to determine any statistical differences between the baby factors but no significant associations were shown.

\section{Discussion Key findings}

The results of this study revealed that $50.3 \%$ of the participants had PND with $48.8 \%$ of the participants with moderate PND in the Witzenberg subdistrict, a rural area of South Africa. Most participants who developed PND were affected by more than one preventable risk factor. The dominant factors contributing to PND in this rural environment were that most participants $64.2 \%$ were unmarried, of which $56.3 \%$ had PND, 55\% of participants with PND were in unsatisfactory relationships, and the majority $60.4 \%$ had unplanned babies, of which $52.5 \%$ of all participants with PND were unplanned. Results have shown that teenage pregnancies in this rural environment could be problematic as $23.8 \%$ of the participants with PND were teenagers. Compounded further is that more than half of the participants $53.8 \%$ who had PND had a history of a psychiatric illness and had experienced a major life event $48.7 \%$. This rural study also showed that 
$59.7 \%$ of the participants were unemployed with the majority $61.3 \%$ of the participants with PND being unemployed.

\section{Discussion of key findings}

The results of this study do not correspond to the worldwide prevalence rate of $12 \%-15 \%$, as found in many of the community surveys of postnatal depression, but is similar to a study which states that some studies have identified PND up to $60 \% .^{27}$ The study revealed that $55 \%$ of the participants with PND were in an unsatisfactory relationship with their partners with a statistical significant difference between partner relationship and depression $(p<0.01)$. These results between partner relationship and PND are aligned with results of a study which found that poor quality of relationships may increase PND. ${ }^{9}$ The lack of partner support, or closeness, or partner abuse is found in nearly one in three of the women with PND. ${ }^{28}$ Therefore, it remains important to have a spouse or partner for protection against developing PND. ${ }^{29}$ Teenage pregnancy contributes to the development of PND. ${ }^{30}$ This is substantiated further in a study which confirms that pregnancy at a very young age may increase the prevalence of PND. ${ }^{9}$ It is thus a concern that in this study 38 (23.9\%) of participants were teenagers, 18-19 years of age of which 19 (50\%) had PND. In this particular region under study, 142 babies were born to teenagers below the age of 18 years over a period of one year, April 2014 March 2015, ${ }^{31}$ which increases the risk for the development of PND amongst teenagers in this region.

Most of the participants (52.5\%) with PND had unplanned babies. These results are aligned with a study ${ }^{8}$ which identified that unplanned pregnancies contribute to maternal depression.

Poor maternal mental health is especially problematic for the infants of these mothers as it reduces the caregiver's sensitivity and responsiveness at a time when a child is entirely dependent on his or her mother's well-being. ${ }^{32}$

\section{Strengths and limitations}

The research was conducted in a rural subdistrict of the Western Cape, South Africa, which included five towns. A quantitative study was conducted using international validated instruments, however a phenomenological qualitative research may provide in-depth experiences about specific factors that influence the development of PND. A limitation of the study was that a convenient sample was drawn of participants who were available, met the criteria and gave voluntary consent to participate in the study. The research was conducted only in the public health services and participants were predominantly of a low socio-economic level.

\section{Implications or recommendations}

The results of this study revealed that the risk factors as discussed and identified in the Witzenberg subdistrict contributed to the development of PND. In most cases,
PND can be prevented and, if diagnosed early, the level of severity and consequences of the problem may be curtailed. The recommendations are thus based on the scientific evidence obtained in this study with specific reference to preventative and promotive measures.

\section{Early assessment}

Early and holistic assessment of the pregnant women during the antenatal period should be done to identify any risk factors and clinical symptoms of depression which may necessitate early referral and/or treatment.

\section{In-service and continuous professional development}

Continuous professional development and in-service training of midwives and primary health care practitioners are recommended. Nurses should be empowered to take the appropriate measures when factors or any symptoms are identified, as supported by Tammentie et al. ${ }^{33}$

\section{Nutritional supplements}

The nutritional status of the patient is specifically important during the antenatal visits as the midwife needs to ensure that the mother understands the importance of a balanced diet and taking her supplements, namely ferrous sulphate and folic acid tablets. There is a strong relationship between iron status and PND. ${ }^{34}$

\section{Prevention of teenage pregnancies}

All stakeholders of the communities, including churches, non-governmental organisations, schools, the South African Police Services and the Departments of Education and Social Development and Health should apply a unified approach in combating social pathologies such as sexual abuse and prostitution, which contribute to the high incidence of pregnancy.

\section{Role of the department of health}

Woman's health is a priority and should be addressed as a priority to ensure healthy women and babies. Standard practices should include prenatal and postnatal classes for mothers and fathers. User-friendly clinics especially designed for teenagers have become essential.

Comprehensive school health programmes must be fully implemented at all schools, such as the 'Health Promoting Schools Initiative', and should include a healthy sexuality programme.

\section{Further research}

Qualitative research is recommended in the low-income rural areas in South Africa to obtain a better understanding of the communities' understanding of mental distress and their mental health needs. In addition, as described, a phenomenological qualitative research may provide in- 
depth experiences about specific factors that influence the development of PND.

\section{Conclusion}

The study has shown an extremely high prevalence of risk factors for the development of PND. Prevention, early detection, appropriate referral and treatment of PND are thus critical in managing maternal, child and family well-being.

\section{Acknowledgements}

Sincere thanks to Prof. Ethelwynn L. Stellenberg for her invaluable support and guidance throughout the study. Thank you to the Directorate of Health and Nursing Management for allowing her to do the study. Furthermore, the researchers appreciate the cooperation of the staff at the clinics and the fieldworkers during this study.

\section{Competing interests}

The authors declare that they have no financial or personal relationship(s) that may have inappropriately influenced them in writing this article.

\section{Authors' contributions}

The article 'The prevalence and factors influencing postnatal depression in a rural community' is based on the research conducted by J.M.A. and supervised by E.L.S. E.L.S (Stellenbosch University) wrote the article for publication which was reviewed by J.M.A.

\section{References}

1. Sadat Z, Abedzadeh-Kalahroudi M, Kafaei Atrian M, Karimian Z, Sooki Z. The impact of postpartum depression on quality of life in women after child's birth. Iran Red Crescent Med J. 2014;16(2):e14995. PMID: 24719747, http://dx.doi. org/10.5812/ircmj.14995

2. United Nations Development Programme. The millennium development goals: Eight goals for 2015 [homepage on the Internet]. No date [cited 2015 Apr 8] Available from: http://www.undp.org/mdg/

3. World Federation for Mental Health. DEPRESSION: A global crisis. 20th Anniversary of World Mental Health Day, October 10 2012. Available from: http://www. who.int/mental_health/management/depression/wfmh_paper_depression wmhd_2012.pdf

4. Mkhizei N, Kometsii MJ. Community access to mental health services: Lessons and recommendations, Ch. 7 [homepage on the Internet]. No date [cited 2015 Apr 8] Available from: http://www.hst.org.za/uploads/files/chap7_08.pdf

5. Currò V, De Rosa E, Maulucci S, et al. The use of Edinburgh Postnatal Depression Scale to identify postnatal depression symptoms at well child visit. Ital Pediatr [serial on the Internet]. 2009;35:32. PMID: 19863812, http://dx.doi. org/1186/1824-7288-35-32

6. Robertson E, Celasun N, Stewart DE. Risk factors for postpartum depression In: Stewart DE, Robertson E, Dennis CL, et al., editors. Postpartum depression: Literature review of risk factors and interventions. Toronto: University Health Network Women's Health Program, 2003; p. 1-63.

7. The National Audit of the Detection and Management of Postnatal Depression Jul 2006 NAPDFinalReport_FINAL030706.pdf. www.healthcareimprovementscotland.org

8. Tomlinson M, Cooper PJ, Stein A, Swartz L, Molteno C. Post-partum depression and infant growth in a South African peri-urban settlement. Child Care Health Dev. 2006;32(1):81-86. PMID: 16398794.
9. Horowitz JA, Goodman JH. Identifying and treating postpartum depression. J Obstet Gynecol Neonatal Nurs [serial on the Internet]. 2005;34(2):264-273. PMID: 15781605, http://dx.doi.org/10.1177/0884217505274583

10. Martin A. Mom with postnatal depression kills babies [homepage on the Internet]. IOL News, World News. 2012 Oct 31 [cited 2013 Jan 15]. Available from: http:// www.IOL.co.za.mht

11. Sellers PM. Midwifery: A textbook and reference book for midwives in Southern Africa. 10th ed. Lansdowne: Juta; 2008.

12. Robertson R, Allwood C, Gagiano C. Textbook of psychiatry for Southern Africa. Cape Town: Oxford University Press; 2005

13. Fraser DM, Cooper MA. Myles textbook for midwives. 15th ed. Philadelphia: Elsevier; 2009.

14. Ramchandani PG, Richter LM, Stein A, Norris SA. Predictors of postnatal depression in an urban South African cohort. J Affect Disord. 2009;113(3):279-284. PMID: 18571734, http://dx.doi.org/10.1016/j.jad.2008.05.007

15. Moultrie A, Kleintjes S. Women's mental health in South Africa. Cape Town: Department of Psychiatry, University of Cape Town, 2005; p. 347-366.

16. Groenewald P. Annual health status report. Boland/Overberg region. Worcester Department of Health; 2006.

17. Cooper PJ, Tomlinson M, Swartz L, et al. Improving quality of mother-infant relationship and infant attachment in socio-economically deprived community in South Africa: Randomized controlled trial. BMJ. 2009;338:b974. PMID: 19366752 http://dx.doi.org/10.1136/bmj.b974

18. Darcy JM, Grzywacz JG, Stephens RL, Leng I, Clinch CR, Arcury TA. Maternal depressive symptomatology: 16-Month follow-up of infant and maternal health-related quality of life. J Am Board Fam Med. 2011;24(3):249-257. PMID 21551396, http://dx.doi.org/10.3122/jabfm.2011.03.100201

19. Paris R, Bolton RE, Weinberg MK. Postpartum depression, suicidality, and mother-infant interactions. Arch Womens Ment Health [serial on the Internet] 2009;12:309-321. PMID: 19728036, http://dx.doi.org/10.1007/s00737-009-0105-2

20. Milgrom J, Gemmill AW, Bilszta JL, et al. Antenatal risk factors for postnatal depression: A large prospective study J Affect Disord. 2008;108(1-2):147-157. PMID: 18067974, http://dx.doi.org/10.1016/j.jad.2007.10.014

21. Statistics South Africa. Census 2011: Municipal factsheet. Pretoria: Statistics South Africa; 2013.

22. Witzenberg District Municipality, Cape Winelands. Witzenberg integrated development plan 2007/2011. Witzenberg; 2007

23. Cox JL, Holden JM, Sagovsky R. Detection of postnatal depression. Development of the 10-item Edinburgh Postnatal Depression Scale. Br J Psychiatry 1987;150(6):782-786. PMID: 3651732, http://dx.doi.org/10.1192/bjp.150.6.782

24. Beck AT, Ward CH, Mendelson M, Mock J, Erbaugh J. An inventory for measuring depression. Arch Gen Psychiatry. 1961;4:561-571. PMID: 13688369, http:// dx.doi.org/10.1001/archpsyc.1961.01710120031004

25. Beck Depression Inventory [homepage on the Internet]. No date [cited 2013 Feb 8] Available from: http://en.wikipedia.org/wiki/Beck_Depression_Inventory\#Twofactor_approach_to_depression

26. StatSoft, Inc. Statistica Data Analysis Software; version 8. 2008. Available from: http://www.statsoft.com

27. Sankapithilu GJ, Nagaraj AKM, Undaru SB, Nanjegowda RB, Nagaraja V. A comparative study of frequency of postnatal depression among subjects with normal and caesarean deliveries. Online Int J Health Allied Sci. 2010;9(2):1-5.

28. Roux G, Anderson C, Roan C. Postpartum depression, marital dysfunction, and infant outcome: A longitudinal study. J Perinat Educ. 2002;11(4):25-36. PMID: 17273318, http://dx.doi.org/10.1624/105812402X88939

29. Tannous L, Gigante LP, Fuchs SC, Busnello ED. Postnatal depression in Southern Brazil: Prevalence and its demographic and socioeconomic determinants. BMC Psychiatry. 2008;3(8):1. PMID: 18173833, http://dx.doi.org/10.1186/1471 244X-8-1

30. Allen JP, Insabella G, Porter MR, Smith FD, Land D, Phillips N. A social-interactional model of the development of depressive symptoms in adolescence. J Consult Clin Psychol. 2006;74(1):55-65. PMID: 16551143, http://dx.doi.org/10.1037/0022006X.74.1.55

31. Ceres hospital statistics: Teenage pregnancies below the age of 18 years; April 2014-March 2015

32. Tomlinson M, Cooper P, Murray L. The mother-infant relationship and infant attachment in a South African peri-urban settlement. Child dev. 2005;76(5):10441054. PMID: 16150001, http://dx.doi.org/10.1111/j.1467-8624.2005.00896.x

33. Tammentie T, Tarkka MT, Astedt-Kurki F, Paavilainen E. Socio demographic factors of families related to postnatal depressive symptoms of mothers. Int J Nurs Pract. 2002;8:240-246. PMID: 12225350, http://dx.doi.org/10.1046/j.1440$172 X .2002 .00373 . x$

34. Beard JL, Hendricks MK, Perez EM, et al. Maternal iron deficiency anemia affects postpartum emotions and cognition. J. Nutr. 2005;135(2):267-272. PMID: 15671224. 